\title{
Naming animals in Chinese writing
}

\author{
Han-liang Chang \\ Department of Foreign Languages and Literatures, \\ National Taiwan University \\ No. 1, Section 4, Roosevelt Road, Taipei, 106 Taiwan \\ e-mail: changhl@ccms.ntu.edu.tw
}

\begin{abstract}
Naming, according to Sebeok, constitutes the first stage of zoosemiotics. This special but common use of language actually inaugurates more complicated procedures of human discourse on non-human kingdom, including classification of its members. Because of language's double articulation in sound and sense, as well as the grapheme's pleremic (meaning-full) rather than cenemic (meaning-empty) characteristic (according to Hjelmslev), Chinese script is capable of naming and grouping animals randomly but effectively. This paper attempts to describe the said scriptorial "necessity of naming" (Kripke) in classical Chinese by citing all the creatures, real or fabulous, with a $/ \mathrm{ma} /$ (horse) radical.
\end{abstract}

Name, according to Thomas A. Sebeok (1975), is one of the six types of sign, and naming constitutes the first stage of zoosemiotics. This first stage is a logical and semiotic necessity that mediates culture and nature because whatever life species and form one sets to describe, he needs naming to encode it in the first place. Here "encoding" runs the pragmatic gamut of designating, referring to, and describing, as well as covering the semantic area of sense (Sinn) and meaning (Bedeutung). While zoosemiotics serves to mediate ethology and semiotics (Sebeok 1975: 87), naming, one could argue, links zoosemiotics and biosemiotics in terms of language function, and more precisely, linguistic pragmatics.

In fact, the four areas of study of biosemiotics outlined by Claus Emmeche (1992): (1) the emergence of semiosis in nature, (2) the natural history of signs, (3) the horizontal aspects of semiosis, and (4) the semiotics of cognition and language, have to be accounted for by a 
natural language which, in Emile Benveniste's words, is at once an interpreting and interpreted system (Benveniste 1981). ${ }^{1}$ Furthermore, to be an interpreting system, this natural language has to develop for itself a descriptive apparatus capable of mapping onto its object of study though it remains controversial whether or not there is a metalanguage and object-language distinction in biosemiotics. One could even assert, following Hjelmslev, that area (4) suggested by Emmeche, "the semiotics of cognition and language", serves as a metasemiotics to encode the previous three areas which are its objectsemiotics (Hjelmslev 1969: 121). ${ }^{2}$ As Hoffmeyer and Emmeche (1991: 118) rightly observe, "Biological information is expressed through signs and should be studied as such, i.e. as a special case of semiotics, which we shall term semiotics of nature". The distinct but inseparable relationship between substance and form suggests the epistemological rupture between traditional versions of biology and their "informational" counterpart. Our co-authors allude (Hoffmeyer, Emmeche 1991: 117) to the etymological distinction between morphology and information to see how the idea of bringing something into form in the Latin verb informare already implies an explanatory metasemiotics in biosemiotics.

This meta-semiotics, or meta-language, if one wishes, according to our co-authors, is code-duality, i.e., "the ability of a system to represent itself in two different codes, one digital and one analog". (ibid.: 126). The hasty equation of the special feature of living organisms to a meta-language may need an explanation, but this formulation lies at the core of Hoffmeyer and Emmeche's model which has the explanatory power for both nature and culture, life and language. ${ }^{3}$ Witness how they describe culture in the same language: "Thus, culture may be seen as built on the code-duality of digital language and analog "reality"' (ibid.: 128).

${ }^{1}$ Note that in Emmeche (1994: 126) the author leaves out language when he asserts that biosemiotics "concerns itself with signs in biological systems, ranging from communication among animals to the individual cell's genetic code as a sign system of its own".

${ }^{2}$ Hjelmslev (1969: 121) points out that "the semiologist who describes semiotics that are not languages will be able to make that description in a language", and that "should this not be the case, the semiotic that is used will in any event always be translatable into a language".

${ }^{3}$ Elsewhere Emmeche and Hoffmeyer (1991: 6) define semiotics of nature the "construction of the analogy between language and the living nature". 
This code-duality serves as a model, a master code that manifests itself in both nature and culture, as succinctly represented in the diagram showing the digitalisation of DNA and language (Figure 1).

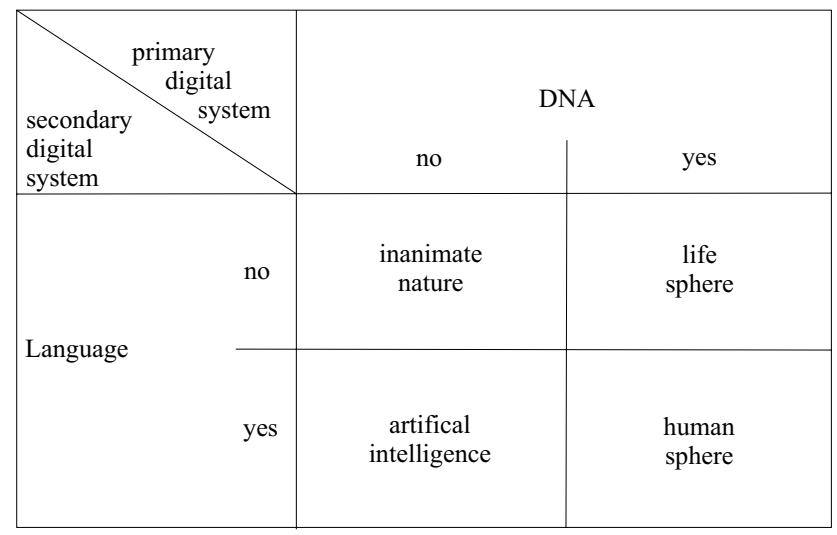

Figure 1. The double digital system of nature (modified from Hoffmeyer, Emmeche 1991: 155).

\section{Elsewhere Emmeche and Hoffmeyer observe,}

Life has its own 'language'. This language, furthermore, resembles human language in one very essential characteristic: it is built upon a digital code, the code of DNA. Now the Saussurean distinction of parole and langue is a distinction inside language - i.e., both parole and langue belong to the linguistic sphere of the digital code of words. Yet, the phenotype - like the species - is of blood and flesh, and as such its eventual communication belongs to the universe of the analog code. (Emmeche, Hoffmeyer 1991: 31)

In talking about naming animals, I would like to take a cue from this observation of self-reference and code-duality, but freely appropriate them with an anthropo-semiotic transposition. The animal I shall be talking about is the horse, and the code-duality phenomenon I shall be introducing is classical Chinese writing. ${ }^{4}$ Hoffmeyer and Emmeche

${ }^{4}$ Humans receive information with their senses: sounds through hearing; images and text through sight; shape, temperature, and affection through touch; and odours through smell. To interpret the signals received from the senses, humans have developed and learned complex systems of languages consisting of alphabets' of symbols and stimuli and the associated rules of usage. This has enabled them to 
assert that self-reference is a fundamental of life, and any system "must be able to construct a description of itself" (Hoffmeyer, Emmeche 1991: 126). However, I shall transpose this to the opposite cognitive realm, i.e., how human beings refer to the horse rather than how it refers to itself. In fact, insofar as scientific meta-language is concerned, and insofar as the observer and the observed are homogeneous, self-reference and other-reference make little distinction in my paper.

Not a biologist, I have chosen to pick up the written form rather than the biological substance of "horse" for reasons that are discursive rather than scientific. I should like to register my paper in a critical discourse which draws on heterogeneous sources, all of which, however, fall under the heading of a general semiotics. Let me begin with an interesting anecdote, the Russian film theoretician Sergei Eisenstein (1949) was once fascinated by the hieroglyph of horse. Although he believed, rightly, that the original features of hieroglyph can no longer be recognised today, they are crystalised in the present form of writing, i.e., the ideogram (Chang, 1988, 1996). Eisenstein's compromise is to leave that poor little horse alone, sagging its lovely hind legs pathetically. Witticism notwithstanding, the anecdote calls our attention to the process of symbolisation of iconic signs and possibly suggests a special kind of the interaction of analogical and digital forms of language information processing.

The second source that serves as an intertext is Claude LéviStrauss's discussion of the naming of four domesticated animals that mediate nature and culture, non-human and human, namely, the birds, the cattle, the dogs, and the horses. In his curious argument, LéviStrauss christens birds as "metaphorical human beings" dogs "metonymical human beings" cattle "metonymical inhuman beings" and racehorses "metaphorical inhuman beings" (Lévi-Strauss 1966: 207). Their psycho-sociological differences can be found on the plane of naming: names of birds and dogs are derived from language

recognize the objects they see, understand the messages they read or hear, and comprehend the signs received through the tactile and olfactory senses. The carriers of information-conveying signs received by the senses are energy phenomena - audio waves, light waves, and chemical and electrochemical stimuli. In engineering parlance, humans are receptors of analog signals; and, by a somewhat loose convention, the messages conveyed via these carriers are called analog-form information, or simply analog information. Until the development of the digital computer, cognitive information was stored and processed only in analog form, basically through the technologies of printing, photography, and telephony. 
[langue] and thus of paradigmatic character; those of cattle and horses from speech [parole], being taken from the syntagmatic chain. LéviStrauss then neatly situates the four animals in a semiotic square (Figure 2), showing their contradictions and contrarieties.

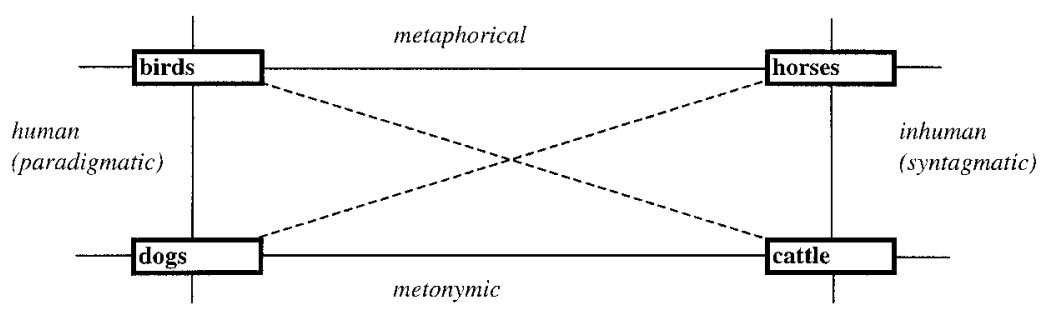

Figure 2. A system of naming animals (from Lévi-Strauss 1966: 208, modified).

It is obvious that Lévi-Strauss's conceptualisation is based on a rather rigid dichotomies between language and speech, syntagmata and paradigmata, metonymy and metaphor, because the roles of mediation of the four domestic animals can be easily transposed and exchanged in different socio-cultural contexts. There are several implications in the structural anthropologist's finding. First, the appellation of animals by proper names can only be an extreme form of domestication and by no means of the concern of zoosemiotics or biosemiotics. Second, the act of naming has extended from common names of animals to proper names and thus put into question the necessity of naming (Kripke 1972). But Saul Kripke has argued, "[C]ertain general terms, those of natural kinds, have a greater kinship with proper names than is generally realized." These include "various species names, whether they are count nouns, such as 'cat', 'tiger', 'chunk of gold', or mass terms such as 'gold', 'water', etc.” (Kripke 1972: 327). Strikingly, all the four animals cited by Lévi-Strauss have entered classical Chinese script via the identical function of iconicity and have become cardinal morphemes for an infinite process of grammaticalisation and semanticisation. At least in ancient China, the domestication of real animals by writing witnesses an important transition of cultural history and the birth and sophistication of literacy. This phenomenon is complicated by the totemic trace that /ma/ or [horse] has become a common family name, and quite a large of number of men have horses, mostly stallions and thoroughbreds, as their first names. 


\section{Han-liang Chang}

Finally, this prolonged digression brings us back to co-authors Hoffmeyer and Emmeche. Earlier I mentioned their code-duality principle of life and language. It may not be a coincidence that they have touched upon the non-alphabetical writing system. "The distinction between analog and digital codes is certainly not a simple one, as is illustrated for instance by the hieroglyphs. While a single hieroglyph may be taken as an analog representation, it becomes digital when presented in written text" (Hoffmeyer, Emmeche 1991: 130).

Let me then begin with a single hieroglyph, that representing [horse] $/ \mathrm{ma3} /$. This is an instance of one of the most primitive categories of ancient script called pictograph, in Peircean terms, iconic sign. This single sign is already a self-contained unit, consisting of a graphic signifier which closes on the signified concept, or more precisely, which directly maps onto the semantic level without the mediation of a phonetic signifier. A sign like this is motivated and, according to Louis Hjelmslev (1959), "pleremic", i.e., semantically-full, as opposed to the alphabetical script based on the phonemic or syllabic level which is "cenemic", i.e., semantically-empty. The connection of the horse's signific $<$ ma $>$ to its phonetic $/ \mathrm{ma3} /$ may have been a historical accident or marriage of convenience. The phonetic aspect, to be sure, can be segmentalised into smaller units, an initial and an ending, as well as the suprasegmental tone, so can be the graphic aspect segmentalised into graphemic components. But neither of these smaller units has a signfunction. The iconicity of simple pictographs conforms to what Hoffmeyer and Emmeche have termed "analog representation".

Then the next problem would be how a single hieroglyph can become or will become digital in the written text. Our authors are obscure at this point. It may refer to the computerised conversion of analog to digital in processing written text which actually is some kind of transcription of speech, as suggested by the popular term of "written language". The assumption is, of course, the much-abused logocentrism which suggests the tyranny of speech. In fact, one of the most popular forms of written Chinese processing usually begins by (1) alphabetising the non-alphabetical script; (2) parsing and tagging the alphabetised script as if it were English. Other than this, processing Chinese script is extremely puzzling and its input problem is entirely different from that of English and any other alphabetical script. For one thing, the pictographic aspect is made complicated by large numbers of homophones and homonyms. The 40,000 strong words (or characters) in the imperial dictionary compiled in the early 18 th century and the 50,000 modern words in use today have only some 
400 sounds. ${ }^{5}$ Recent advances have witnessed the digitalisation of the analog script by means of algorithm and other techniques. Unfortunately, achievements so far have been limited to the cognition and processing of individual characters or images, and have not been able to deal with issues of syntax and discourse without alphabetisation. Rather than getting into these, I shall try to tackle the problem of signification by analysing the horse icon. One may recall that Peirce already introduces the concept of interpretant to mediate the sign and its object. The interpretant attributes an "imputed quality" (semantics) to the object which is realised in the sign via the latter's "material quality" (Peirce 1982, 3: 66). The idea of interpretant suggests, among other things, that it requires shared knowledge among users who accept the sign to be used as such. This enables the pictograph to lend itself as morphographeme to form a more complex sign, such as an ideograph, or is loaned to represent visually a morphophoneme, morpheme, or lexia which does not have a grapheme and graphic sign of its own. In both cases, the iconic sign either transforms into an indexical sign or is appropriated as a symbolic sign.

Thus the original iconic sign $<\mathrm{ma}>$ is appropriated as a morphographeme and added to another loaned morpho-grapheme which no longer has any semantic function but serves as a morphophoneme. Now an infinite number of horse family members, so to speak, are engendered. These are almost always ideographic, composed by a morphographme of horse $<\mathrm{ma}>$, and a morphophoneme, which is taken randomly from the paradigmatic category, to differentiate one horse from another in pronunciation. They can be classified into at least four groups (Figure 3).

Group 1 consists of some dozen words referring to different kinds of horses, such as the cluster of liu, hua, jun, ji, qi, jiao all denoting thoroughbreds; and the cluster of horses in different Umwelts, such as can [left horse of a war chariot], and fei [right horse of a war chariot], $y i$ [stagecoach horse].

Group 2 include words which "refer" to animals which are perceived, perhaps mistakenly, as belonging to the horse family, such as luo [mule], lyu [donkey], luo [camel] or [llama].

${ }^{5}$ An international research group was formed in New York in 1976 called the Chinese Language. Computer Society to dedicate itself to Chinese information processing (Yu et al. 1988). 


\section{Han-liang Chang}

Group 3 contains verbs with a horse morpheme but transformed into verbs, such as tuo [carry \{on horseback\}], qu [drive], jia [steer], shi [drive], qi [ride]. The transposition of nominal system to verbal system is made possible by metonymical contiguity.

Group 4 comprises of some curious instances where a morphophoneme added to the [horse] totally erases both the denotation and connotation of horse. An example is pian, meaning [cheat].

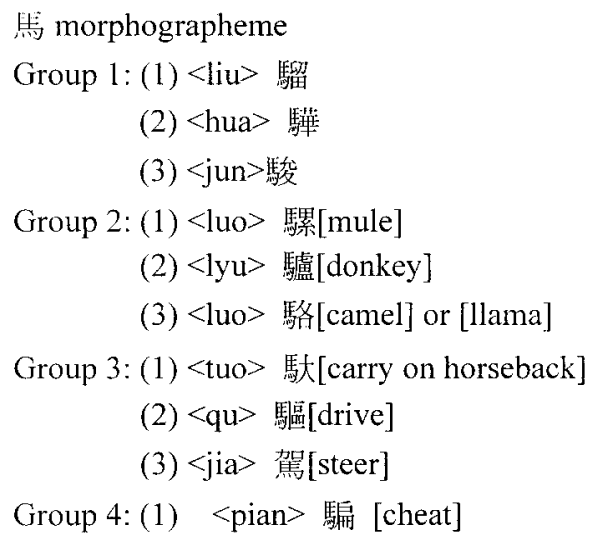

Figure 3. Classes of words with a $<\mathrm{ma}>/ \mathrm{ma} 3 /$ [horse] morphographeme.

Now these four clusters are all generated from two steps. The first step is the transformation of the horse icon from the graphemic level to the morphographemic level; and the second step, paradigmatic substitutions from within the existing language, in particular, lexical system. The principle of differentiation is arbitrary and make-shift. One could say that it is both necessary and contingent; in other words, it is arbitrary a priori, but conventional a posteriori.

Words in Group 4 indicate the script's tendency towards arbitrary symbolisation. It is made possible by the generation of new graphic signs, either through addition or through loan. This category now constitutes the largest group of Chinese words. They can be called hypographs. The hypograph is governed by the principle of appropriation, which allows individual graphic signs to bear secondary meanings. Sometimes, the "signific" of a graph is loaned to coin new graphs; other times, the "phonetic" is loaned. There are also occasions 
when the whole graphic sign is loaned by virtue of homophonicity. This multiplication of characters and usages is acclerated by graphoand phono-syntaxisation. Grammatically, most deictics, anaphoras, prepositions, postpositions, and conjunctions that contribute to characters' distribution on the axis of syntax fall into this category. Today the expression which consists of two reduplications of the horse and tiger icons, $/ \mathrm{ma} / / \mathrm{ma} / \mathrm{hu} / / \mathrm{hu} /$, literally [horse] [horse] [tiger] [tiger], means, however, "floppy". And the expression $/ \mathrm{ma} /$ /shang/, literally [horse] [up], means "immediately". Such expressions are extremely popular in spoken Chinese. Their generative-transformational process can be certainly approximated by digitalisation, but the mystery of their etymology cannot be explained by any method known to us.

\section{References}

Barthes, Roland 1967. Elements of Semiology. Trans. Lavers, Annetten; Smith, Colin. New York: Hill and Wang.

Benveniste, Emile 1981. The semiology of language. In: Genette, Ashby; Russo, Adelaide (eds.), Semiotica, Special Supplement, 5-23.

Chang, Han-liang 1988. Hallucinating the Other: Derridean Fantasies of Chinese Script. (Working Paper 4, Fall 1988). Milwaukee: UW-Milwaukee, Center for Twentieth Century Studies.

- 1996. Semiographemics: A Peircean trichotomy of classical Chinese script. Semiotica 108(1): 31-43.

Eisenstein, Sergei 1949. Film Form: Essays in Film Theory. Leyda, Jay (ed.). New York: Harvest-Harcourt Brace Jovanovich.

Emmeche, Claus 1994. The Garden in the Machine: The Emerging Science of Artificial Life. Trans. Sampson, Steven. Princeton: Princeton University Press.

Emmeche, Claus; Hoffmeyer, Jesper 1991. From language to nature: The semiotic metaphor in biology. Semiotica 84(1): 1-42.

Hjelmslev, Louis 1959. Essais linguistiques. (Travaux du Cercle linguistique Copenhague 12.) Copenhagen: Akademisk Forlag.

- 1969. Prolegomena to a Theory of Language. Trans. Whitfield, Francis J. Madison: University of Wisconsin Press.

Hoffmeyer, Jesper; Emmeche, Claus 1991. Code-duality and the semiotics of nature. In: Anderson, Myrdene; Merrell, Floyd (eds.), On Semiotic Modeling. Berlin: Mouton de Gruyter, 117-166.

Kripke, Saul 1972. Naming and Necessity. In: Davidson, Donald; Harman, Gilbert (eds.), Semantics of Natural Language. Dordrecht: De Reidel, 252-355.

Lévi-Strauss, Claude 1966. The Savage Mind. Chicago: University of Chicago Press. 


\section{Han-liang Chang}

Peirce, Charles Sanders 1982. Writings of Charles S. Peirce: A Chronological Edition. Vols. 1-4. Fisch, Max H.; Moore, Edward C.; Kloesel, Christian J. W. (eds.). Bloomington: Indiana University Press.

Sebeok, Thomas A. 1975. Zoosemiotics: At the intersection of nature and culture. In: Sebeok, Thomas A. (ed.), The Tell-Tale Sign: A Survey of Semiotics. Lisse: Peter de Ridder, 85-95.

- 1994. An Introduction to Semiotics. Toronto: University of Toronto Press.

- 1997. The evolution of semiosis. In: Posner, Roland; Robering, Klaus; Sebeok Thomas A. (eds.), Semiotics: A Handbook on the Sign-Theoretic Foundations of Nature and Culture. Berlin: Walter de Gruyter, 437-446.

$\mathrm{Yu}$, Wellington C. P; The Hoon-Heng; Low Hwee-Boon; Yan Xin; Gao Fang 1988. A Historical Advancement of the Chinese Language Computing. Computing Processing of Chinese and Oriental Languages 4(3): 57-81.

\section{Называние животных в китайском письме}

Согласно Себеоку, называние составляет первый этап зоосемиотики. Это специальное, но в то же время обычное употребление языка ведет к более сложным процедурам (в том числе и классификации) человеческого дискурса, касающегося внеположенного человеку мира. Поскольку язык артикулирован вдвойне (в звуке и в мысли) и по причине скорее плерематического чем кенематического (в терминах Ельмслева) характера графемы, в китайском письме имеется возможность называть и группировать животных случайно, но в то же время эффективно. Данная статье пьтается описать скрипториальную "необходимость называния" (Крипке) на классическом китайском языке, рассматривая всех животных, как реальных, так и сказочных, в названии которых встречается основа/ма/ (лошадь).

\section{Loomade nimetamine Hiina kirjas}

Nimetamine, nagu ütleb Sebeok, moodustab zoosemiootika esimese etapi. See erakordne, kuid levinud keelekasutus juhatab tegelikult sisse inimriigist väljapoole jäävat puudutava inimdiskursuse keerukamad toimingud, sealhulgas ka sellesse kuuluva klassifitseerimise. Keele topeltartikuleerituse tõttu helis ja mõttes ning ka grafeemi pigem plereemilise (tähendusliku) kui keneemilise (tähendustühja) iseloomu tõttu (nagu väidab Hjelmslev) on Hiina kirjas võimalik loomi nimetada ja rühmitada juhuslikult, kuid samas tõhusalt. See artikkel teeb katse kirjeldada eespoolmainitud skriptoriaalset "nimetamise paratamatust" (Kripke) klassikalises hiina keeles, käsitledes kõiki olendeid, nii tegelikke kui ka muinasjutulisi, kelle nimes esineb morfografeem /ma/ (hobune). 